\title{
The Role of Criminal Investigator in Disabilities Persecution
}

\author{
Ali Mashuri*) \\ *)Student of Master of Law, Faculty of Law, Universitas Islam Sultan Agung \\ (UNISSULA) and Head of Police Sector in Tambakromo, Pati, E-mail: \\ alimashuri006@gmail.com
}

\begin{abstract}
.
The aim of this study is to know the procedures for the role of investigators in investigating criminal acts of persecution of victims of disabilities. Role of Investigators in Investigating Criminal Acts of Persecution of Victims. Factors obstructing the role of Investigators in investigating criminal acts of abuse of victims of disabilities at the Police. This study uses an approach method juridical empirical The conclusion of this study is Procedure for investigating criminal acts of mistreatment of victims of disabilities at Tambakromo Police. The law enforcement process begins based on the report: LP/B/392020/Jateng/Res.Pt/Sek.Tbr. Making Reports, Visiting the Crime Scene, Recording witnesses, Report to the leadership, conduct an investigation. The role of investigators in investigating criminal acts of persecution of victims of disabilities at Tambakromo Police. Based on the Police Report Number: LP/B/392020/Jateng/Res.Pt/Sek.Tbr. January 13, 2020; Investigation warrant Number: SP. Sidik/01.A/I/2020/Reskrim, dated January 13, 2020; Letter of notification of commencement of investigation Number: SPDP/01/I/Res. 1.6/2020/Reskrim, 17 January 2020; then Crime Scene Arrest, Detention, Confiscation, Statement of witnesses, statement of the suspect Visum Et Repertum, Evidence. factors inhibiting the role of the investigator in investigating the criminal act of assaulting victims of disabilities at the Tambakromo Police, Whereas the report of the incident of the case with the case that is reported is a long difference so that the investigator in the process of conducting the examination of the witness is constrained in the witness summoning, because the witness cannot be present at the appointed time. Lack of human resources for investigators, lack of infrastructure in the investigation, and how to deal with it Coordinating with victims so that witnesses who are presented when summoned can be present at the office according to the time specified, Supervise and inspect every activity and administrative worksheets made by assistant investigators, Lack of budget submitted for the following year, but rarely realized. Keywords: Investigator; Crime; Persecution; Disability.
\end{abstract}

\section{Introduction}

The police are a state agency in charge of creating and maintaining security. According to Satjipto Raharjo, the police are state instruments whose task is to maintain security and public order, provide protection and provide protection to the public. ${ }^{1}$ Furthermore, he quoted this opinion stating that if the law aims to create order in society, including the war against crime. Finally, the police will determine in concrete terms what is called a law enforcement order. ${ }^{2}$

\footnotetext{
${ }^{1}$ Raharjo , Satjipto. (2009). Law Enforcement A Sociological Review of Gentang. Publisher Yogyakarta p. 111. In Jurnal Daulat Hukum. Volume 1 Issue 3 September 2018 ISSN: 2614-560. http: //garuda.ristekbrin.go.id/documents/detail/1755554

2 Ibid. p. 117
} 
Crime is an act that is against the law, these actions are also detrimental to society, in the sense that it contradicts and or hinders the implementation of the order in social relations is considered good and fair. ${ }^{3}$ Crime can only be prevented and reduced because it is very difficult to completely eradicate. Law enforcement is carried out by law enforcement officials, law enforcement officials who are at the forefront of dealing directly with the community and who implement all existing laws and regulations in order to create discipline in society, especially when a crime occurs, the police are the first to handle it. To know more clearly about the main duties of the police in general, see Article 13 of Act No. 2 of 2002 Concerning Indonesian National Police which stated:

Main Duties of the Indonesian National Police:

- Maintain public security and order;

- Enforce the law; and

- Providing protection, protection, and services to the community.

By looking at the main duties of the police, it is known that the police exercise social control in the community, both preventive (prevention) and repressive (eradication). ${ }^{4}$ In connection with the repressive nature of the police's duties, this cannot be separated from the role of the police in the judicial sector. In justice, the police have the duty to carry out investigations and investigations. Investigation is the stage of completing a criminal case after an investigation, which is the initial stage of looking for the presence or absence of a criminal act in an event. When it is known that a criminal act has occurred, that is when an investigation can be carried out based on the results of the investigation. In the act of investigation, the emphasis is placed on the act of "looking for and finding" an "event" which is considered or suspected to be a criminal act. Whereas in investigation the emphasis is placed on the action of "seeking and gathering evidence".

The aim of the education is to make clear the criminal acts found and also determine the perpetrators. In the provisions of criminal law in the Criminal Code, investigations are carried out by general investigators, namely Police investigators. The investigator is the police apparatus of the Republic of Indonesia for at least two assistants to the Lieutenant (Moda) Police (now two Assistant Police Inspectors). ${ }^{5}$ According to the statement Hartono, with a background of advanced thinking and not limited to what is written in legislation alone, law enforcement by investigators can be said to be a model of "progressive investigation". And with a combination of the scientific investigation approach and progressive investigation, it is hoped that it can realize proportional, professional, and intellectual law enforcement. ${ }^{6}$

The meaning of investigation is contained in Article 1 point 2 of the Criminal Procedure Code, namely in Chapter I regarding General Elucidations, namely:

\footnotetext{
${ }^{3}$ Bassar, M. Sudradjat Bassar. (1985). Tindak-tindak Pidana Tertentu di Dalam Kitab Undang-undang Hukum Pidana. Bandung: Remadja Karya. p. 2

${ }^{4}$ Raharjo, Satjipto. (2007). Membangun Polisi Sipil. Jakarta: Kompas Book Publisher. p.25

${ }^{5}$ Sugandar, Ferry Anka Sugandar. (2009). Teaching materials for Criminal Procedure Law. Pamulang University, Tangerang in Jurnal Daulat Hukum Volume 1 Issue 3 September 2018 ISSN: 2614-560. http://garuda.ristekbrin.go.id/documents/detail/1755671

${ }^{6}$ Hartono. (2010). Penyidikan dan Penegakan Hukum Pidana Melalui Pendekatan Hukum $\begin{array}{lllll}\text { Progresif. Jakarta: Sinar } & \text { Grafika. Jakarta, } & \text { p. }\end{array}$ http://jurnal.unissula.ac.id/index.php/jurnalhukum/article/view/659
} 
"Investigation is a series of actions by an investigator in matters and according to methods regulated in this law to seek and collect evidence with that evidence to make clear about the crime that occurred and in order to find the suspect ".

Meanwhile, the Criminal Procedure Code itself is regulated in Law of the Republic of Indonesia Number 8 of 1981 concerning Criminal Procedure Law. Based on the formulation of Article 1 point 2 of the Criminal Procedure Code, the elements contained in the meaning of investigation is:

- Investigation is a series of actions that contain interrelated actions between one another

- Investigations are carried out by public officials called investigators.

- Investigations are carried out based on statutory regulations.

- The purpose of the investigation is to find and collect evidence, with that evidence to make clear the criminal act that occurred, and find the suspect.

Based on these four elements, it can be concluded that prior to an investigation, a criminal act was known, but the criminal act was not yet clear and it was not known who did it.

According to de Pinto, to investigate (Opsporing) means the preliminary examination by officials who are for this purpose appointed by the law as soon as they have in any way heard news that is just as grounded, that there has been a law violation. ${ }^{7}$ So that if there is a report or complaint by an individual or the public regarding a criminal act committed by a person or group of people, the police are obliged to immediately follow up on the report or complaint.

The function of the investigation is not only to find suspects but can also be used to find a series of criminal acts that have occurred. In the investigator's activities to collect evidence, authorities are given certain actions to him, so that it is possible to complete the investigation and be ready to submit it to public prosecutor: ${ }^{8}$

An example of a case that occurred in Tambakromo District was a disability named Sugiyo bin Warsidin (alm.) who became a victim of persecution by the suspect Rasimin known as Jeprik bin Loso (alm.). The victim was tortured by the way the suspect pulled the victim's leg from the front, then after the victim fell on his back, the victim's body was occupied by the suspect, then the victim's face was kicked with a shoe 2 (two) times, after which the victim's chest was kicked 3 ( three) times, then hit the face of the victim 5 (five) times, after that the victim's neck was stepped on 2 (two) times, then the neck of the victim was choked and then a resident came to interrupt the incident. As a result of the incident, the victim then reported to the Tambakromo Police.

\section{Research Methods}

This study uses an approach of empirical juridical, then the specification in this research is descriptive analysis. According to Dyah Ochtorina and A'an Efendi, empirical juridical research includes research on legal identification (unwritten law)

\footnotetext{
${ }^{7}$ Hamza, Andi. (2008). Hukum Acara Pidana Indonesia. Jakarta: Sinar Grafik Offset. p.120

8 Prakoso, Djoko. (1986). Peranan Psikologi Dalam Pemeriksaan Tersangka Pada Tahap Penyidikan. Jakarta: Ghalia Indonesia. p.51
} 
and research on legal effectiveness. ${ }^{9}$ Descriptive research is research that aims to describe something in a certain area and at a certain time. ${ }^{10}$ The sources and types of data in this study are primary data obtained from field studies by interviews and secondary data obtained from studies.

\section{Results and Discussion}

\subsection{Procedure for investigating criminal acts of mistreatment of victims of disabilities at the Tambakromo Police Sector}

A criminal act is an act that can lead to the punishment of a person for his actions which have been determined by the criminal law. So that the handling of each criminal case is different, according to existing laws.

The law enforcement process begins based on reports or complaints of criminal acts. As an example of a criminal case of persecution that occurred in Gares Hamlet, Wukirsari Village, Tambakromo District, Pati Regency, a disabled resident named Sugiyo bin Warsidin (alm.) became a victim of persecution. In this incident, the victim suffered non-material losses in the form of bruises on the right chest, bruises on the right and left cheeks, then a torn mouth, bleeding and bruises on the neck. As a result of the incident, the victim then reported to the Tambakromo Police, Pati Regency with the report number: LP/B/392020/Central Java/Res.Pt/Sek.Tbr.

Whereas based on the report, Tambakromo District Police Headquarters. Pati takes the following actions:

- Make a report

- Visit the crime scene

- Recording witnesses

- Report to the leadership

- Carry out an investigation

\subsection{The role of investigators in investigating criminal acts of persecution of victims of disabilities at the Tambakromo Police Sector}

\subsubsection{Basic}

- Police Report Number: LP/B/392020/Jateng/Res.Pt/Sek.Tbr. January 13, 2020;

- Investigation warrant Number:SP. Sidik/01.A/I/2020/Reskrim, dated January 13, 2020;

- Letter of notification of commencement of investigation Number: SPDP/01/I/Res. 1.6/2020/Reskrim, 17 January 2020.

\subsubsection{Case}

\footnotetext{
${ }^{9}$ Susanti, Dyah Ochtorina \& A'an Efendi. (2014). Penelitian Hukum (Legal Research). Jakarta: Sinar Grafika. p.18

10 Soemitro, Ronny Hanitijo. (1982). Metodologi Penelitian Hukum dan Jurimetr. Jakarta: Ghalia Indonesia. p.93
} 
On Thursday 17 October 2019 at 07.00 West Indonesia Time in the victim's rice field, precisely at Geres Hamlet, Wukirsari Village Rt 02 Rw 03 Dist. Tambakromo Reg. Pati, there has been a criminal act of mistreatment against the victim, Mr. Sugiyo bin (alm.) Warsidin, age: 49 years old, religion: Islam, occupation: private, Address: Geres Hamlet Wukirsari Village Rt 02 Rw 03 Dist. Tambakromo Reg. Pati which was carried out by the suspect Mr. Rasimin known as Jeprik bin (alm.) Loso, Age: 71 Years, religion: Islam, Occupation: Farmer, Address: Geres Hamlet Wukirsari Village Rt 02 Rw 03 Dist. Tambakromo Reg. Pati.

The suspect, Mr. Rasimin known as Jeprik bin (alm.) Loso by the way the suspect pulled the victim's leg from the front then after the victim fell on his back the victim's body was occupied by the suspect, then the victim's face was kicked using shoes 2 (two) times after that the victim's chest was kicked 3 (three) times then the victim's face was hit 5 (five) times, after which the victim's neck was stomped on 2 (two) times, then the neck of the victim was strangled and the witness came to him. Suwadi bin Karmin and witnesses Br. Wawan Indra Saputra bin Karimun who intervened the persecution incident at that time, after which the suspect was withdrawn by witnesses Br. Suwadi bin Karmin and when he was withdrawn the suspect still kicked the victim 2 (two) times, hitting his mouth and chest 1 (one) time.

As a result of this incident, the victim suffered non-material losses in the form of bruises on the right chest, bruises on the right and left cheeks, then a torn mouth, bleeding and bruises on the neck.

For this act, the suspect Br. Rasimin known as Jeprik bin Loso was threatened as referred to in article: 351 paragraph (1), paragraph (4) of the Criminal Code.

\subsubsection{The Facts}

- Crime scene arrests

The first action at the scene of the case is to secure the scene of the incident, maintain the status quo/situation, make a crime scene sketch, and make a BA at the crime scene, collect evidence, seek information, and record witnesses.

- Summons

In this case no summons were made

- Arrest

With an arrest warrant number: SP. Kap/01/2020/Reskrim, January 14, 2020, an arrest was made of Mr. Rasimin known as Jeprik bin (alm.) Loso, age: 61 years, religion: Islam, occupation: farmer, Address: Geres Hamlet Wukirsari Village Rt 02 Rw 03 Dist. Tambakromo Reg. Pati. Furthermore, an official report of his arrest is made.

- Detention

With a detention warrant number: SP. Han/20/I/2020 Reskrim, 15 January 2020, the suspect has been detained. Rasimin known as Jeprik bin (alm.) Loso, \pm age: 61 years, religion: Islam, Occupation: Farmer, Address: Geres Hamlet Wukirsari Village Rt 02 Rw 03 Dist. Tambakromo Reg. Pati. Furthermore, Minutes of Detention are made.

With a letter of detention from the Pati Regency Prosecutor's Office number: B-27/M.316/Equ.1/01/2020, dated January 30, 2020, the detention of the suspect 
has been extended. Rasimin known as Jeprik bin (alm.) Loso, age: 61 years, religion: Islam, Occupation: Farmer, Address: Geres Hamlet Wukirsari Village Rt 02 Rw 03 Dist. Tambakromo Reg. Pati. For an extension of detention starting from February 4, 2020 to March 14, 2020.

With the detention extension warrant number: SP.Han/20.B/II/2020/Reskrim, dated February 03, 2020, the detention extension of the suspect Mr. Rasimin known as Jeprik bin (alm.) Loso, age: 61 years, religion: Islam, Occupation: Farmer, Address: Geres Hamlet Wukirsari Village Rt 02 Rw 03 Dist. Tambakromo Reg. Pati. Furthermore, Minutes of Detention are made.

- Foreclosure

- Statement of witnesses

- Description of the suspect.

- Visum Et Repertum

- Evidence

\subsection{Factors inhibiting the role of investigators in investigating criminal acts of persecution of victims of disabilities at the Tambakromo Police Sector}

Based on the results of an interview with AIPTU Suprapto, SH as the assistant investigator at Tambakromo Police, Pati Regency said that the inhibiting factors in carrying out an investigation were; 11

- Whereas the time difference between the case and the reported cases is so that the investigator in the process of conducting the examination of witnesses is constrained by the summoning of witnesses, because the witness cannot attend at the appointed time.

- Lack of human resources for investigators

- Lack of infrastructure in the investigation.

\section{Conclusion}

Procedure for investigating criminal acts of mistreatment of victims of disabilities at Tambakromo Police. The law enforcement process begins based on the report: LP/B/392020/Jateng/Res.Pt/Sek.Tbr. Making Reports, Visiting the Crime Scene, Recording witnesses, Report to the leadership, conduct an investigation. The role of investigators in investigating criminal acts of persecution of victims of disabilities at Tambakromo Police. Based on the Police Report Number: LP/B/392020/Jateng/Res.Pt/Sek.Tbr. January 13, 2020; Investigation warrant Number: SP. Sidik/01.A/I/2020/Reskrim, dated January 13, 2020; Letter of notification of commencement of investigation Number:SPDP/01/I/Res. 1.6/2020/Reskrim, 17 January 2020; then Crime Scene Arrest, Detention, Confiscation, Statement of witnesses, statement of the suspect Visum Et Repertum, Evidence. factors inhibiting the role of the investigator in investigating the criminal act of assaulting victims of disabilities at the Tambakromo Police, Whereas the

11 Interview with AIPTU Suprapto as Assistant Investigator at Tambakromo Police Sector on 20 September 2020 
report of the incident of the case with the case that was reported is a long difference so that the investigator in the process of conducting the examination of the witness is constrained in the witness summoning, because the witness cannot be present at the appointed time. Lack of human resources for investigators, lack of infrastructure in the investigation.

\section{References}

Journal:

[1] Hartono. (2010). Penyidikan dan Penegakan Hukum Pidana Melalui Pendekatan Hukum Progresif. Jakarta: Sinar Grafika. Jakarta, p. 10 http://jurnalunissula.ac.id/index.php/jurnalhukum/article/view/659

[2] Raharjo, Satjipto. (2009). Law Enforcement A Sociological Review of Gentang. Publisher Yogyakarta p. 111. In Jurnal Daulat Hukum. Volume 1 Issue 3 September $2018 \quad$ ISSN: 2614-560. http: //garuda.ristekbrin.go.id/documents/detail/1755554

[3] Sugandar, Ferry Anka Sugandar. (2009). Teaching materials for Criminal Procedure Law. Pamulang University, Tangerang in Jurnal Daulat Hukum Volume 1 Issue 3 September 2018 ISSN: 2614-560. http://garuda.ristekbrin.go.id/documents/detail/1755671

Books:

[1] Bassar, M. Sudradjat Bassar. (1985). Tindak-tindak Pidana Tertentu di Dalam Kitab Undang-undang Hukum Pidana. Bandung: Remadja Karya

[2] Hamza, Andi. (2008). Hukum Acara Pidana Indonesia. Jakarta: Sinar Grafik Offset

[3] Prakoso, Djoko. (1986). Peranan Psikologi Dalam Pemeriksaan Tersangka Pada Tahap Penyidikan. Jakarta: Ghalia Indonesia

[4] Raharjo, Satjipto. (2007). Membangun Polisi Sipil. Jakarta: Kompas Book Publisher

[5] Soemitro, Ronny Hanitijo. (1982). Metodologi Penelitian Hukum dan Jurimetr. Jakarta: Ghalia Indonesia

[6] Susanti, Dyah Ochtorina \& A'an Efendi. (2014). Penelitian Hukum (Legal Research). Jakarta: Sinar Grafika

Interview:

Interview with AIPTU Suprapto as Assistant Investigator at Tambakromo Police Sector on 20 September 2020 